\title{
Status of Approval Plans in College Libraries
}

\section{Beth E. Jacoby}

The author surveyed college libraries in the United States to determine their use of approval plans as a method of acquiring printed books for their collections. Survey results indicate recent trends over a five-year period, including shelf-ready books, e-notifications, and virtual approval plans as well as impending use of approval plans for e-books. Findings show a correlation between the size of the library book budget and the likelihood of having an approval plan. The author also presents results from an informal survey of domestic approval plan vendors on the status of the scholarly monograph market and its effect on approval plan use. While the number of books acquired through approval plans may have decreased slightly, overall approval plan use in college libraries has not declined. The approval plan continues to evolve and is an effective, time-saving tool for librarians pressed for time in a rapidly changing digital world.

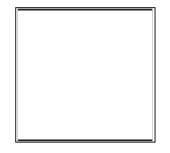

irst developed by the Richard Abel Company in the 1960s to help libraries spend a surplus of book money, the approval plan is now more than four decades old. Large research libraries have long used approval plans to aid in the development of research collections to support broad undergraduate and in-depth graduate programs. Use of approval plans in smaller college libraries, on the other hand, has not been as widespread largely due to budgetary and philosophical reasons.

An approval plan is an arrangement between a library and a book vendor to provide newly published books or, less commonly, other types of resources such as music scores or compact discs. The library and vendor work together to set up a profile that contains both subject and nonsubject parameters. The vendor then matches publishing output against the profile. If a newly published title matches the library's profile, the vendor automatically ships it for library staff or faculty to review and determine if they want to keep or "approve" the book for their collection. If there is a partial match against the profile, the vendor sends a paper slip or form containing bibliographic information about a particular title. The library can then decide if it wants to generate an order based on the information on the bibliographic slip.

In light of the current discussions regarding the decline of the scholarly printed book, is the approval plan still an effective means for academic libraries, particularly college libraries, to acquire books? At a time when the focus of librarians and their budgets are on digital rather than print resources, has the role of the book in academia been diminished to the point that the approval plan is no lon-

Beth E. Jacoby is Collection Development Librarian at York College of Pennsylvania; e-mail: bjacoby@ycp. edu. 
ger an effective and relevant acquisitions tool? The purpose of this article is to examine the current status of approval plan use in college libraries based on results from a survey of small and mid-sized college libraries as well as discussions with several academic book vendors.

\section{Literature Review}

According to the 1997 ARL SPEC kit on approval plans, 93 percent of Association of Research Libraries (ARL) respondents used approval plans. This study concluded that "ARL libraries still consider approval plans to be efficient and cost effective." ${ }^{11}$

The reasons most cited for using approval plans were "the freeing of selectors to focus on the elusive, while relying on approval to collect material from mainstream publishers; greater price discounts; staff time savings; review with book-in-hand; timely receipt of current imprints; and consolidated ordering." ${ }^{2}$

Use of approval plans in small and mid-sized libraries has not been as widely accepted as in ARL libraries. Since the early days of approval plans, critics have argued that college libraries do not have sufficient funds to support an approval plan. This argument maintains that it is too difficult to set up a profile that sufficiently limits the huge number of newly published books so as not to deplete the materials budget and still pay for subscriptions, standing orders, and other discretionary purchases. Other primary reasons cited for not using approval plans have included the belief that librarians should not let a vendor select books for them, and that approval plans take too much staff time to administer. ${ }^{3}$

Proponents of approval plans have argued that the plans are as appropriate for college libraries as large research libraries. In 1985, Kevil of the Baker \& Taylor Company stated that the under utilization of approval plans by college libraries stemmed from "imperfect perceptions of what an approval plan can and cannot actually do, from lack of knowledge of how to make the plan work and derive maximum benefit from it." ${ }^{4}$ Kevil refuted the arguments against approval plans and stated that they can work in college libraries with book budgets as small as $\$ 50,000$. A decade later, Wittenberg of Blackwell North America also argued that more college libraries could realize the cost and coverage benefits of instituting approval plans. Libraries with budgets of $\$ 50,000-\$ 200,000$ can use approval plans to help balance their collections, which would otherwise grow in a lopsided fashion based on uneven levels of faculty participation and their temporary research needs. ${ }^{5}$

The feasibility of instituting an approval plan at a small college library was tested in the early 1990s at the Ogontz Campus Library at Pennsylvania State University. Dole tested Kevil's theory by setting up an approval profile to support basic instruction in general arts and sciences and checking the vendor-supplied lists to see how many and which titles would have been supplied had the approval plan been activated. Based on the findings at her library, she concluded that "approval plans do not work well below a certain budget level unless there is some other distinct factor, such as limiting the plan to certain publishers or subjects." 6 Niles came to a different conclusion for approval plan use at Carleton College. She found that size of budget was not the critical factor in determining the success of their approval plan but that library versus departmental selectors made a difference. She also concluded, however, that a comprehensive approval plan did not make sense at her library and opted for a forms-only plan to cover current publishing output.?

In 1999, Blecic, Hollander, and Lanier published results of a survey of academic health sciences libraries in the United States and Canada on their use of approval plans. Those results indicated that the increased cost of serials subscriptions, budgetary constraints, and growth of electronic resource acquisitions had re- 
sulted in a decline in print acquisitions, which forced the curtailing of approval plans in many academic health sciences libraries. ${ }^{8}$ The present paper explores whether these same trends have curtailed approval plan use in liberal arts college libraries with their broad-based but mostly undergraduate curricula.

\section{Methodology}

The survey instrument developed by Blecic, Hollander, and Lanier to assess the use of approval plans in academic health sciences libraries was adapted and updated for use with liberal arts college libraries. The adaptations reflected the differences between health sciences and liberal arts libraries as well as the recent trends in approval plans: for example, the use of electronic notification forms. The adapted survey was posted on the COLLIB-L and ACLCP-L listservs in February 2006. Both of these listservs target small and mid-sized college libraries. COLLIB-L is a national listserv, whereas ACLCP-L serves the regional membership of the Associated College Libraries of Central Pennsylvania, a consortium of academic and research libraries that serves mostly undergraduate liberal arts colleges.

In addition to the library survey, the author conducted an informal survey in December 2005 of the four remaining traditional approval plan vendors in the United States. The purpose of the survey was to elicit their views and gather data on the status of the market for scholarly monographs and approval plans. The author asked the vendors to provide data on the number of approval plans they serviced in 2000 compared to 2005 to ascertain if the number of plans had increased, decreased, or held steady. Unfortunately, confidentiality concerns prevented all four vendors from supplying the proprietary data that would have allowed for a meaningful comparison between the two years in question. In one instance, the lack of data from 2000 due to a change in computer systems prevented a comparative analysis. The vendors did, nonetheless, provide general assessments on the status of the approval plan and overall trends in the academic bookselling industry.

\section{Library Survey Results}

Of the 114 survey responses, 88 were complete enough to include in the results, although not all questions were answered by those 88 libraries; therefore, in some cases, the total responses fell below 88 . A majority of libraries included in the survey are baccalaureate-granting institutions, some of which also offer a small number of masters programs. Nearly 69 percent of the libraries have print monograph collections of less than 300,000 volumes. Of the remaining libraries, 18 percent have $300,001-500,000$ volumes,

\begin{tabular}{|l|c|c|c|c|c|}
\hline \multicolumn{7}{|c|}{ TABLE 1 } \\
\hline & \multicolumn{7}{|c|}{ Mrofile of Monograph Collection and Budget Size of Surveyed Libraries } \\
\hline \hline Monograph Budget & $\begin{array}{c}\text { Less than } \\
\mathbf{1 0 0 , 0 0 0} \text { vols }\end{array}$ & $\begin{array}{c}\mathbf{1 0 0 , 0 0 0}- \\
\mathbf{3 0 0 , 0 0 0} \text { vols }\end{array}$ & $\begin{array}{c}\mathbf{3 0 0 , 0 0 1}- \\
\mathbf{5 0 0 , 0 0 0} \text { vols }\end{array}$ & $\begin{array}{c}\text { More than } \\
\mathbf{5 0 0 , 0 0 0} \text { vols }\end{array}$ & Totals \\
\hline Less than $\$ 50,000$ & 13 & 3 & 1 & - & 17 \\
\hline$\$ 50,000-149,000$ & 8 & 22 & 6 & - & 36 \\
\hline$\$ 150,000-299,999$ & - & 6 & 3 & 4 & 13 \\
\hline$\$ 300,000-500,000$ & - & 4 & 4 & 3 & 11 \\
\hline Over $\$ 500,000$ & 1 & 2 & 2 & 4 & 9 \\
\hline Totals & 22 & 37 & 16 & 11 & - \\
\hline Note: 86 respondents answered these questions. & & & & \\
\hline
\end{tabular}




\begin{tabular}{|l|c|c|c|c|c|}
\hline \multicolumn{7}{|c|}{ TABLE 2 } \\
\hline Relation of Book Budget to Approval Plan Use \\
\hline Monograph Budget & $\begin{array}{c}\text { Total No. of } \\
\text { Libraries }\end{array}$ & $\begin{array}{c}\text { Libs With } \\
\text { No Plan }\end{array}$ & \% Without & $\begin{array}{c}\text { Libs With } \\
\text { Plan }\end{array}$ & $\%$ With \\
\hline Less than $\$ 150,000$ & 53 & 42 & $79 \%$ & 11 & $21 \%$ \\
\hline$\$ 150,000$ or more & 35 & 12 & $34 \%$ & 23 & $66 \%$ \\
\hline Totals & 88 & 54 & & 34 & \\
\hline
\end{tabular}

and only 13 percent have more than 500,000 volumes. Many respondents $(41 \%)$ had only $\$ 50,000-\$ 149,000$ to spend on monographic acquisitions in fiscal year 2005-2006. The budgets of the other respondents are shown in table 1 , a profile of both monograph collection and budget size among participating libraries.

The survey asked libraries if their materials budgets had kept pace with inflation and price increases in the five-year period between 1999-2000 and 2004-2005. Not surprisingly, for most of the libraries $(82 \%)$, book budgets had not kept pace with inflation and price increases. Fortyfive percent of the libraries experienced decreases in their book budgets, and another 25 percent had flat book budgets over that five-year period. Taking into account the effects of inflation, this in essence means that 70 percent of the libraries had less money to spend on books either because of a decrease in real dollars or because of inflation erosion. On the other hand, 47 percent reported increases in their serials budgets and 87 percent had increases in electronic resources funding. No libraries had a funding decrease for electronic resources. Most likely, many of these libraries had reallocated some of their book money to support the increased cost of serials and to enable the addition of new electronic resources.

In addition to giving information about how their budgets had changed over a five-year period, libraries also gave an appraisal of whether they were buying more, less, or the same number of certain types of materials. Compared to five years ago, 60 percent of surveyed libraries indicated receiving fewer print books, while 44 per- cent reported getting more e-books. Many libraries $(60 \%)$ are also canceling standing orders for print titles and subscribing to fewer journals (67\%). Almost all libraries $(91 \%)$ are receiving more electronic resources than five years ago. These numbers support the common observation that libraries have been shifting their funds from print books to electronic resources.

There were more libraries in the survey that do not currently use an approval plan $(61 \%)$ than do use one $(39 \%)$. Those that do not have a current plan cited limited book budget $(70 \%)$ and philosophy of selection $(49 \%)$ as the primary reasons for not using a plan. There was a clear correlation between the size of the library book budget and the likelihood of having an approval plan. (See table 2.) Of the 53 libraries that had less than $\$ 150,000$ to spend on books, only 21 percent had an approval plan. In contrast, of the 35 libraries that had book budgets of $\$ 150,000$ or more, 66 percent had approval plans.

Among the 34 libraries (39\%) that currently use approval plans, 68 percent use just one plan, while 21 percent use two or more plans. Four approval plan libraries did not answer the question regarding the number of plans in use. The three primary reasons cited for having an approval plan were saving staff time (85\%), supplementing title coverage that would otherwise be missed by selectors (64\%), and improved efficiency over reviewing publisher catalogs (58\%). Less common but still significant reasons for using the plans included saving money (33\%), little or no faculty interest in book selection $(30 \%)$, subject-based vendor expertise $(21 \%)$, and shelf-ready books (18\%). 
Among the approval plan libraries in the survey, 34 percent had multidisciplinary plans; 26 percent, disciplinespecific plans; and 18 percent, publisherbased plans. About a third of the libraries still get bibliographic slips as part of their approval plans, but nine libraries indicated that they have dropped paper slips within the past five years. Whereas no libraries received e-notifications five years ago, 20 percent did as of the survey date. This change seems to point toward a trend away from paper slips toward electronic title notification. Another trend has been the use of shelf-ready plans. With shelfready plans, the profile-matched books arrive at the library with spine labels, pockets, and other preprocessing by the vendor, so they are nonreturnable. Five years ago, none of the surveyed libraries had shelf-ready plans, but 9 percent currently do.

Ten of 81 libraries (12\%) cancelled an approval plan in the past five years. Budget constraints (5 libraries) topped the list of reasons for shutting down an approval plan. The second most-cited reason was the shift from print to e-resources (3 libraries). Other reasons for canceling a plan included increased cost of e-resources and serials, vendor performance problems, and profiling problems.

Seventeen of 84 libraries (20\%) have added or are considering adding an approval plan either because they do not currently have one or because they want an additional plan to cover areas not covered by their existing plans. The main reason libraries are considering adding approval plans is to supplement selector coverage or cover titles that selectors may otherwise miss (88\%). Other top reasons for adding a plan include the higher efficiency of approval plans over the review of publisher catalogs or Web sites (53\%), little or no faculty interest in book selection $(35 \%)$, and desire for subject-based vendor expertise (29\%).

Due to the increased interest in digital formats, the survey asked librarians to indicate whether they would consider us- ing an approval plan to acquire e-books. Of the 85 libraries that responded to the question, 7 percent said yes, 44 percent said no, and 49 percent said maybe. It is unclear whether the large number of "no" responses was in reaction to acquiring e-books via an approval plan, the use of approval plans regardless of print or electronic format, or the acquiring of ebooks in general.

As indicated in the literature review, one of the reasons college libraries have given for not using approval plans has been selection philosophy. In other words, some librarians believe they do a better job than vendors in selecting individual titles based on their knowledge of local curriculum. More and more resources, however, are being offered in large publisher or vendor-defined packages such as the NetLibrary and ebrary e-book collections. For this reason, the survey asked if title-by-title selection is better than acquiring resources in packages. A majority of survey respondents (69\%) believe that to be the case.

Libraries have been increasingly utilizing Internet bookstores to acquire books that would previously have been purchased from a traditional academic book vendor. To gauge whether this competition between book vendors and Internet bookstores has had an effect on approval plans, the survey requested libraries to indicate if and how much they use Internet bookstores. Eighty-five percent of respondents reported using an Internet bookstore to purchase at least some of their books. Most of the libraries (76\%) use Internet bookstores for less than 25 percent of their book purchases; however, 13 percent use this method to acquire more than 50 percent of their books.

\section{Vendor Survey Results}

The four domestic approval plan vendors were asked to comment on trends in the scholarly monograph market. Three of the four vendors described the market as stagnant or challenged due to the shift in funding from print to online resources. As 
libraries accommodate increased faculty and student demand for online resources and as the cost of e-journals and online databases increases, libraries have fewer funds to purchase printed books. One vendor put forth the contrarian view that the market remains strong for scholarly books.

Published statistics support the view that spending for print scholarly monographs is declining. The Association of Research Libraries (ARL) reports that its members increased spending on e-content while expenditures for monographs as well as the number of monographs purchased fell from 2003 to $2004 .^{9}$ Similarly, statistics from the Canadian Association of Research Libraries (CARL) show that its members also spent less on print monographs during the same period. ${ }^{10}$ Further evidence in the decline in print book sales is available from the American Association of University Presses, which has reported an overall decrease in book sales among its members of 1.5 percent in 2003 , on top of a 0.3 percent reduction in 2002 and a 2.6 percent drop in $2001 .^{11}$

This trend is not limited to the large academic libraries. As stated above, 45 percent of small and mid-sized academic libraries surveyed for the present study have experienced decreases in their materials budgets for print books between 1999-2000 and 2004-2005. Another 25 percent of surveyed libraries reported a flat book budget, which translates into fewer books purchased due to inflation. In the words of one book vendor, "a confluence of technology, social factors and rising print costs (especially for journals) is definitely impacting the print monograph market. Whether the effects will steadily rise or remain on the same tentative path is debatable."12

While the book vendors painted a somewhat bleak picture of the health of the scholarly monograph, the majority was more optimistic about the health of approval plans. Their responses about the status of approval plan use ranged from "good" to "much in demand" to "very healthy." The optimism of the majority sprang from the belief that approval plans continue to be a useful selection tool for librarians who are increasingly pressed for time. As the focus of academic libraries has turned to acquiring more e-resources, librarians have little time to scour publisher catalogs, Web sites, and other announcements for print resources, so they continue to need help with narrowing the universe of publishing output to those resources that are most relevant to their constituents. Another vendor gave the opinion that the overall health of approval plans is good because of increasing demand for consortial support and shelfready books.

Only one vendor described the approval plan market as "under some strain." In this dissenting opinion, the vendor sees a decline in approval plan use, not because it is not a useful tool, but because of the competition of funds for e-resources and journals.

While no industrywide statistics exist to show whether the number of approval plans have increased, decreased, or held steady over the past five years, one vendor indicated that the number of academic approval plans has not diminished but that new plans are achieved only by winning them from competing vendors. This same vendor believes the approval plan remains a useful tool for libraries because it allows for the acquisition of core book titles and frees librarians to concentrate on the more elusive titles. Approval plans are also needed in those cases where there is little to no faculty involvement in selection, and to provide subject coverage when there is no selector subject expertise.

One vendor provided a statistical breakdown of the number of books sold in broad subject categories in 2000-2001 compared to 2004-2005, which indicated that the number of humanities and social sciences books decreased only slightly, by one-half percent and 1 percent respectively. On the other hand, the number of science, technology, and medicine (STM) 
books sold decreased by 12 percent. It is unknown whether the large STM decrease is indicative of an industrywide trend or perhaps an overall decrease in the number of STM books sold by that particular vendor.

When asked if they were experiencing an increase in demand from academic libraries for e-books, the responses were mixed. Two vendors indicated a marked increase in demand. The third vendor indicated there had been no strong demand as yet but were actively making preparations in anticipation of increased demand. The fourth vendor replied that there had been an increase in interest but not necessarily an increase in demand. Two vendors are partnering with aggregated e-book providers such as E-book Library (EBL), ebrary, and netLibrary to prepare for the integration of print and electronic books. Another vendor has established a new division within the company to handle the management and provision of e-books. These three companies view e-books as playing an increasingly important role in the provision of scholarly content and, therefore, playing a significant role in the future viability of their companies. The fourth vendor is currently not planning to provide e-books.

The three vendors that are currently supplying e-books have developed the ability to match new e-books to approval profiles in the same way as printed books. One vendor described its e-book approval plan as matching a book against a profile, much like a traditional bibliographic slips plan. When the matching process is complete, the vendor notifies the library with bibliographic information about the relevant e-books. The library then has the option to add those titles to its e-book collection or not.

\section{Discussion}

The results of the library survey support the view that the size of a library's book budget has a direct relationship to the likelihood of using an approval plan. The feasibility of constructing a traditional subject-based approval profile sufficiently narrow to cover a liberal arts curriculum becomes less likely the smaller the book budget. A library with less than $\$ 150,000$ to spend on books would find it hard to bring in core titles without also getting a significant number of peripheral titles. Such a library runs the risk of either depleting its book budget prior to year-end or being overwhelmed with bibliographic slips to review or automatically shipped books to return.

A publisher-based plan, however, could sufficiently focus the profile so as to make an approval plan feasible for a library with a book budget under $\$ 150,000$. Casserly states that "although many large university and research libraries rely on subject-based plans, these may not be suitable for smaller libraries." ${ }^{13}$ She goes on to say that college and smaller university libraries may find that publisher-based plans are "more affordable, more easily managed, and more politically acceptable to faculty and administration." 14

Another option for a college library with a small book budget may be to take advantage of the growing trend toward the virtual approval plan. As defined by Stephen Pugh, the virtual approval plan "is not a review mechanism for e-books, but a way to evaluate printed material prior to purchase by means of linked metadata." 15 The present study indicates a small but growing number of libraries abandoning paper bibliographic slips in favor of electronic notifications of new titles. The premise behind the virtual approval plan, however, goes beyond simply making book selections based on electronically delivered bibliographic citations. The virtual approval plan would include not only the bibliographic description of the book, but links to the table of contents, excerpts, cover images, author biographies, reviews, and other information that would help inform a selector's decision. In short, the virtual approval plan would eliminate paper slips, automatically shipped books, and book-in-hand selection. It would instead 
provide "slips on steroids." ${ }^{16}$ Whether this abundance of metadata would facilitate the selection process or simply add to librarians' information overload is debatable.

Librarians increasingly give book selection short shrift when compared to the amount of time spent evaluating electronic resources. The idea of librarians pouring over book reviews, excerpts, author biographies, and other metadata for each title under consideration does not seem realistic. The reality for most librarians is that the demands on their time prevent more than a cursory glance at the bibliographic descriptions for most titles. Trolling through a large amount of titlerelated information would be reserved only for the most expensive titles.

Virtual approval plans could, nonetheless, provide some relief for collection development librarians by reducing the universe of published materials to those that are most relevant to a particular library. Libraries that use approval plans have found that the identification of potentially relevant titles is more efficient using an approval plan than wading through publisher catalogs. Limiting the approval profile by publisher narrows the universe of titles to consider even further. In the words of Joan Worley, "There need not be a difference between college libraries and other libraries in their ability to make effective use of approval plans. Informed profiling, constant monitoring, and careful review of approval plans must be the rule if they are to succeed in any setting. Given a fair chance, they can be a godsend." 17

The development of shelf-ready books has eased the burden of title-by-title review at some libraries. Because the preprocessed books are nonreturnable, many libraries with shelf-ready plans do not review the books. Shelf-ready approval plans may never be popular among college libraries because they put book selection squarely in the hands of the vendor rather than the librarians and faculty. Results of this survey indicate that the philosophy of title-by-title book selection is still strong among college librarians, and there is a reluctance to acquire books, whether print or electronic, in large predefined packages.

The findings of this survey suggest that the use of approval plans to acquire e-books has not yet garnered wide support among college librarians. Fortyfour percent of respondents expressed no interest in using an approval plan for e-books, and another 49 percent are on the fence, perhaps waiting to see if user demand for e-books increases. This reluctance may be indicative of a larger resistance to acquiring e-books regardless of acquisition method. In spring 2006, librarians at York College of Pennsylvania visited over 700 students in 35 classes across many disciplines in preparation for developing a new long-range plan. Many students commented that they still want and expect the library to have print books. The desire that the library continue providing print books was expressed by students in a wide range of disciplines, not just humanities. As Walt Crawford proclaims, "Print books work. Most readers see no need to replace print books."18

While e-books work well for reference, e-reserve, distance education, and other quick uses, they do not work well for reading a large amount of text in one sitting. The printed book is still superior at conveying in-depth, carefully developed treatises that do not lend themselves to cut-and-paste uses. At the same time, there is some evidence that e-books actually increase the demand for their print counterparts. Recent discussions with e-book providers indicate that users find information they want in an e-book, view an average of 11 to 13.5 pages, then request the print equivalent to read the rest of the book. ${ }^{19}$ Faculty and students use e-books, but they still want print books, too.

Internet bookstores like Amazon.com and Barnesandnoble.com have increased competition for business formerly held by 
traditional academic book vendors. The competition has intensified as libraries and their users have come to expect and demand rapid delivery of ordered books. Eighty-five percent of libraries surveyed use an Internet bookstore to purchase at least some of their books.

In an effort to capture more of the library market, Amazon.com developed a "Monthly Approval Slip" service that was designed to notify libraries automatically via e-mail about newly published books. Their subject categories, however, were too broad to be useful to academic libraries. To address this concern, Amazon.com recently unveiled a new method of setting up a profile that involves a keyword Boolean search with delimiters such as publisher and language. This fledgling notification service has none of the sophistication of a traditional approval plan with its refined subject distinctions and many nonsubject parameters such as price caps and study levels. It's also unlikely that Amazon. com will provide the kind of value-added services and level of customer service that traditional academic book vendors have been providing for years. Perhaps that is why most surveyed libraries use the more impersonal Internet bookstores for less than 25 percent of their book purchases. On the other hand, traditional vendors would do well to take heed that 13 percent of surveyed libraries rely on the Internet to acquire more than 50 percent of their books. For those libraries whose main concern is speed of delivery, the Amazon.com notification service may be sophisticated enough to serve their approval needs.

\section{Conclusion}

Since its inception, the approval plan has evolved to meet the needs and demands of academic librarians. Over time, it evolved to include paper notification slips, MARC records, and interactive databases that, among other features, show inventory and enable report-generating capabilities. Over the past five years, the approval plan has continued its transformation by introducing nonreturnable shelf-ready plans, offering virtual selection via electronic bibliographic notification, and providing order-to-invoice EDI capabilities. Most recently, approval plans hold the promise of assisting libraries with the acquisition of e-books. While there have always been those who denigrated the approval plan, the fact that it has survived for over four decades is a tribute to its success.

Overall approval plan use in college libraries has not declined. The results of the author's survey show that the number of college libraries considering approval plan use or adding a plan to an existing plan is greater than the number canceling their plans. While the number of books acquired through approval plans may be decreasing slightly due to inflation and competition with electronic resources, there is no indication that the approval plan method itself has diminished in usefulness. It continues to be an effective, time-saving tool for librarians who are increasingly pressured to devote their time to activities other than book selection. The transformation of the approval plan will continue as long as libraries continue to buy books and librarians continue to look for ways to save time in a rapidly changing digital world.

\section{Notes}

1. Evolution E Status of Approval Plans: A SPEC Kit, ed. Susan Flood (Washington, D.C.: Association of Research Libraries, Office of Management Services, 1997), Introduction.

2. Ibid.

3. Guy R. Lyle, The Administration of the College Library, 4th ed. (New York: Wilson, 1974), 189-90; R. Santos, "Materials at a Small College Library," in LJ Special Report \#11: Collection Management (New York: Bowker, 1979), 13.

4. L. Hunter Kevil, "The Approval Plan of Smaller Scope," Library Acquisitions: Practice and Theory 9 (1985): 13. 
5. R. Charles Wittenberg, "Approval Plans for College Libraries: Strategies for Smaller Collections," Against the Grain 8, no. 4 (Sept. 1996): 22.

6. Wanda V. Dole, "Feasibility of Approval Plans for Small College Libraries," in Collection Development in College Libraries, ed. Joanne Schneider Hill, William E. Hannaford, Jr., and Ronald H. Epp (Chicago: American Library Association, 1991), 160.

7. Ann Niles, "An Approval Plan Combined with Faculty Selection," in Collection Development in College Libraries, 163-69.

8. Deborah D. Blecic, Sue Hollander, and Don Lanier, "Collection Development and Outsourcing in Academic Health Sciences Libraries: A Survey of Current Practices," Bulletin of the Medical Library Association 87, no. 2 (Apr. 1999): 178-86.

9. Martha Kyrillidou and Mark Young, "ARL Library Trends, 2003-2004," Association of Research Libraries. Available online from www.arl.org/stats/arlstat/04pub/04intro.html. [Accessed 2 October 2006].

10. Ellen Hoffmann, "CARL Statistics, 2003-2004: Trends and Observations," Canadian Association of Research Libraries. Available online from www.carl-abrc.ca/projects/statistics/pdf/ comm_2003-2004-e.pdf. [Accessed 2 October 2006].

11. Barbara Fister and Kiko Pfund, “We're not dead yet!” Library Journal 129 (Nov. 15, 2004). Available online from www.libraryjournal.com/article/CA479162.html. [Accessed 2 October 2006].

12. Sources at Blackwell's Book Services, e-mail message to author, December 22, 2005.

13. Mary F. Casserly, "Collection Development in College and University Libraries: A Comparison," in Collection Development in College Libraries, 11.

14. Ibid.

15. Stephen Pugh, "The Decline of the Poultry Selector: Thoughts on the Virtual Approval Plan," Against the Grain 14, no. 3 (June 2002): 32.

16. Ibid.

17. Joan H. Worley, "The Importance of Being Small: Collection Development in the College Library," Collection Development in College Libraries, 15. 44.

18. Walt Crawford, "Why Aren't E-books More Successful?" EContent, 29, no. 8 (Oct. 2006):

19. Linda Vendryes (Senior Vice President of Strategic Development, MyiLibrary) reported an average of 11 pages viewed per e-book, and Eileen Gardiner (Project Director, ACLS History E-Book Project), an average of 13.5 pages, in discussions with the author, PALINET Annual Meeting, Harrisburg, Penn., October 24, 2006. ACLS also tracks which e-books are requested via their Print-on-Demand service. 


\section{APPENDIX \\ Survey Instrument}

\section{Use of Approval Plans in College Libraries}

A research project is underway to determine the current "health" of approval plans in academic libraries. I need your help to gather data for this study, the results of which I plan to publish. I'm interested in why libraries use approval plans in a digital age, as well as why they do not.

By completing the following questionnaire, you are consenting to participate in this study. Your responses will be confidential and no individual results of this study will be reported.

1. Which of the following job titles best fits your position?

$\square$ Director

$\square$ Assistant director

$\square$ Collection development librarian

Technical services librarian

Acquisitions librarian

$\square$ Reference librarian

$\square$ Other (please specify)

2. Please indicate which of the following degrees your institution offers. (Check all that apply.)
$\square$ Associate
$\square$ Baccalaureate
$\square$ Masters
$\square$ Doctoral

3. What is the approximate size of your print monograph collection?

$\square$ Less than 100,000 volumes
$\square$ 100,000-300,000 volumes
$\square 300,001-500,000$ volumes
$\square$ More than 500,000 volumes

4. What is the approximate amount of your monograph acquisitions budget this fiscal year?

Less than $\$ 50,000$

- $\$ 50,000-\$ 149,999$

口 \$150,000-\$299,999

口 $\$ 300,000-\$ 500,000$

$\square$ Over $\$ 500,000$

5. Approximately what percentage of your FY2004-2005 library materials budget was spent on:
Serials
口 0 40 81-100
Monographs

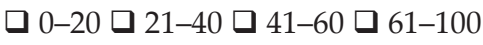
Binding

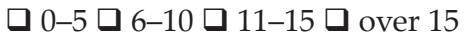
Electronic resources

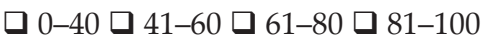
Audio/Video

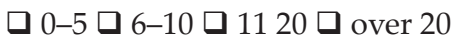

6. In the last five years, has your library materials budget kept pace with inflation and 
price increases? $\square$ Yes $\square$ No

7. In the last five years, has your materials budget for books:

$\square$ Increased $\square$ Decreased $\square$ Not changed 1

Approximate percentage $\square$ 0-5 $\square$ 6-10 $\square$ 11-20 $\square$ over 201

8. In the last five years, has your materials budget for serials:

$\square$ Increased $\square$ Decreased $\square$ Not changed 1

Approximate percentage $\square$ 0-5 $\square$ 6-10 $\square$ 11-20 $\square$ over 201

9. In the last five years, has your materials budget for electronic resources:

$\square$ Increased $\square$ Decreased $\square$ Not changed 1

Approximate percentage $\square 0$-5 $\square$-10 $\square$ 11-20 $\square$ over 201

10. Compared to five years ago, please indicate if your library is receiving fewer titles, the same number, or more titles in each of the following categories: (Check one for each material type.)

$\begin{array}{lccc} & \text { Fewer } & \text { Same } & \text { More 1 } \\ \text { Print books } & \square & \square & \square \\ \text { E-books } & \square & \square & \square \\ \text { Standing order title } & \square & \square & \square \\ \text { Serials/journals } & \square & \square & \square \\ \text { Electronic resources } & \square & \square & \square \\ \text { Audio/video resources } & \square & \square & \square\end{array}$

Definition: An approval plan is an agreement with a commercial vendor that automatically supplies books and/or notification forms to the library according to a predefined profile (subject, publisher, format, price, etc.) and is generally subject to return privileges. Please answer the following questions based on this definition of an approval plan.

11. Does your library currently use one or more approval plans? $\square$ Yes $\square$ No

12. How many separate approval plans does your library use?

$\square 1 \square 2 \square 3 \square 4$ or more $\square$ Not applicable

13. If your library uses an approval plan, why? (Check all that apply.)

$\square$ Saves staff time

$\square$ Saves money

Faculty has little or no interest in book selection

$\square$ Subject-based vendor expertise

$\square$ Covers titles that selectors may otherwise miss

$\square$ More efficient than reviewing publisher catalogs/Web sites

$\square$ Shelf-ready books

$\square$ Other (please describe):

$\square$ Not applicable

14. If your library does not use an approval plan, why not? (Check all that apply.)

$\square$ Philosophy of selection

Book budget too limited 
Institutional purchasing policy

$\square$ Focus on building digital rather than print collections

$\square$ Other (please describe)

$\square$ Not applicable

15. Has your library canceled one or more of its commercial vendor approval plans in the past five years? (Exclude canceling a plan to switch vendors.) $\square$ Yes $\square$ No

16. If you answered yes to $\# 15$, why did you cancel your plan(s)? (Check all that apply.)

$\square$ Budget constraints

$\square$ Increased cost of serials

$\square$ Increased cost of e-resources

$\square$ Shift from print to e-resources

$\square$ Profiling problems

$\square$ Vendor performance problems

$\square$ Other (specify)

Not applicable

17. Has your library added an approval plan in the past five years or is considering adding an approval plan? (Exclude adding a plan to switch vendors.) $\square$ Yes $\square$ No

18. If you answered yes to \#17, why? (Check all that apply.)

$\square$ Cut in staffing

$\square$ Save money

$\square$ Faculty has little or no interest in book selection

Subject-based vendor expertise

$\square$ Covers titles that selectors may otherwise miss

$\square$ More efficient than reviewing publisher catalogs/Web sites

$\square$ Shelf-ready books

$\square$ Significant increase in book budget

$\square$ Other (please describe)

Not applicable

19. Please mark below any or all items that reflect the status of your approval plan use.

$\begin{array}{lccc} & \text { Within } & \text { Current } & \text { Never } \\ \text { last } 5 \text { years } & \text { (but not currently rec'd) } & \\ \text { Multidiscipline approval plan } & \square & \square & \square \\ \text { Discipline-specific plan } & \square & \square & \square \\ \text { Publisher-based plan } & \square & \square & \square \\ \text { Paper forms received } & \square & \square & \square \\ \text { E-notifications received } & \square & \square & \square \\ \text { Shelf-ready plan } & \square & \square & \square\end{array}$

20. When approval books are received, they are:

$\square$ Reviewed for approval/rejection $\square$ Accepted without review/not shelf-ready

$\square$ Accepted without review/shelf-ready $\square$ Not applicable

21. Has the number of approval titles received and kept by your library changed in the last five years? $\square$ Increased $\square$ Decreased $\square$ Not changed $\square$ Not applicable 
22. Would you consider using an approval plan to acquire e-books?

$\square$ Yes $\square$ No $\square$ Maybe

23. Over the past 5 years, the amount of time spent by librarians at your institution on book selection has: $\square$ Increased $\square$ Decreased $\square$ Not changed

24. Philosophically speaking, do you believe that title-by-title book selection is better than selecting books in large packages?

$\square$ Yes $\square$ No $\square$ Depends. Please explain:

25. Do you currently use an Internet book store such as Amazon.com or Barnesandnoble.com to purchase books for your library? $\square$ Yes $\square$ No

If yes, indicate the approximate percentage:

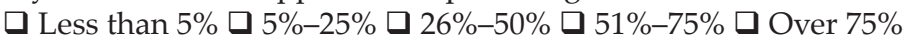

26. Please feel free to provide any comments that you feel would be helpful in describing your library's use of approval plans and their role in collection development for college libraries.

Comments:

Thank you very much for your contribution to this project. Surveys completed by March 17, 2006, will be included in the survey results.

Beth Jacoby

Collection Development Librarian

York College of Pennsylvania 


\section{Classic References from Bernan Press}

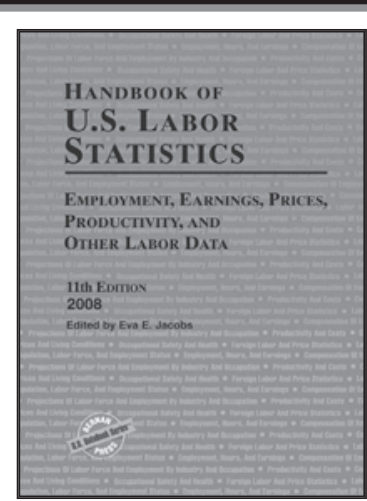

\section{Handbook of U.S. Labor Statistics}

Recent and historical data on U.S. employment, earnings, prices, productivity, living conditions, and related topics in one convenient, single-volume source.

"Essential. Business, economics, or labor collections, lower-division undergraduate or higher."

Selected as an "Outstanding Reference Source" by the Reference and User Services Association

$\begin{array}{ll}\text { May 2008 } 1500 p . & \text { Hardcover } \\ \text { ISBN: } 9781598881806 & \$ 154.00\end{array}$

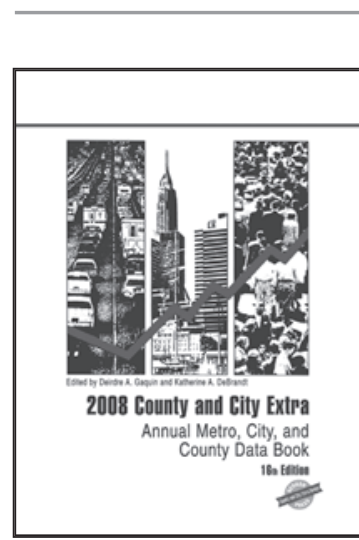

\section{County and City Extra}

Provides data for every U.S. state, county, metropolitan area, Congressional district, and all cities with populations above 25,000 .

"Unique in its coverage...packed with invaluable details." — Library Journal

"A convenient compilation of frequently sought local and state data... clearly organized and well presented making the volume useful for reference collections in public, college, and university libraries."

$$
\text { —Journal of Government Information }
$$

June 2008 1550p. Hardcover

ISBN: $9781598881837 \quad \$ 126.00$

\section{BUSINESS}

STATISTICS

OF THE

UNITED STATES

PATIERN OF ECONOMic Change

13 th Eomox

2008

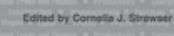

\section{Business Statistics of the United States} A comprehensive overview of the U.S. economy, bringing together into one source data relevant to economic performance regardless of which agency originates them.

"The book is a classic reference on the U.S. economycomprehensive, authoritative, and convenient."

- American Reference Books Annual

"Recommended. All collections."

$$
\text { - } \mathrm{CHOICE}
$$

June 2008 1650p. Hardcover

ISBN: $9781598881820 \quad \$ 154.00$
Call 18008653457 or visit www.bernan.com to place your individual or standing order for these books.
BernanPress 